\title{
Determinants of Dividend Policy of petroleum firms in Nigeria
}

\author{
Dr. Zayol Patrick I ${ }^{1}$, Mr. Mya Ayangealu Theophilus ${ }^{2}$, Miss. Muolozie Mirian ${ }^{3}$ \\ ${ }^{1}$ Department of Accounting and finance Federal university of Agriculture, Makurdi-Nigeria \\ ${ }^{2}$ Department of Accounting and Finance Federal university of Agriculture, Makurdi-Nigeria \\ ${ }^{3}$ Department of Accounting and Finance Federal university of Agriculture, Makurdi-Nigeria
}

\begin{abstract}
This study evaluates the determinants of dividend policy of petroleum firms in Nigeria. The extent to which profitability, firm size, liquidity and leverage affects the dividend payout of petroleum firms in Nigeria triggered this research work. To this end, data was obtained from nine petroleum firms in Nigeria from 2011 2014. Data were analysed using descriptive statistics, correlations and regression analysis. Findings from the study revealed that firm size, liquidity and leverage does not affect the dividend policy of petroleum firms in Nigeria, while profitability was found to affect the dividend policy of petroleum firms in Nigeria. The study concludes that profitability is one of the most considered determinants of dividend policy by listed petroleum firms in Nigeria. The study recommended that investors in petroleum industry who prefer to have dividends yearly should invest in more profitable firms as they tend to pay more dividends.
\end{abstract}

Keywords: Dividend Policy, Profitability, Firm Size, Liquidity and Leverage

\section{Introduction}

Financial managers are generally engage varying critical and important decisions like investment portfolios, product development, and financing, with the objective to increase market value of the firm (Afza \& Mirza, 2011). Distribution of generated profits is another essential management decision. Managers have to decide carefully these amounts of earnings to be distributed to shareholders and the portion of earnings to be reinvested in the business. Earnings distributed to shareholders are called dividend (Pandey, 2004). Dividend is not just a source of income for shareholders, but act as an indicator to judge the performance of the firm (AlMalkawi, Rafferty \& Pillai, 2010). Each company formulates its own policies as regards dividend. This mostly is determined by many factors and conditions prevailing during that period. Dividend policy indicates the level of earnings paid to shareholders on their investment. Dividend policy is a critical decision because it relates with other financial and investment decisions (Abor \& Bokpin, 2010).

Dividend policy, in the context of this study, relates to firm's dividend payout policy that managers follow in deciding the pattern and size of cash distribution to shareholders over time. It is the decision of management about the portion of income that is given to shareholders in the form of dividend. Dividend policy is an important aspect of corporate finance and has gained considerable attention of researchers providing theories, hypothesis and explanations as regards to the distribution of income to company's shareholders after retaining a specific amount of earnings to be reinvested in the business.

Researchers commence debate on dividend policy after Miller and Modigliani, (1961) averred that dividend policy is irrelevant to firms' value but rather is affected by investment policies of the firm under perfect market assumption. Gordon, (1963) negated the argument of Miller and Modigliani in presenting his Bird in hand theory. According to Gordon, (1963), the increase in dividends can influence shareholder wealth positively because of imperfect information and uncertainty in the market. Later on, many other theories contributed in the literature. The signalling theory of Bhattacharya, (1979) explained that under asymmetry of information, dividends can convey information about the future prospects of a firm. Easterbrook, (1984) presented the agency cost theory, which suggests that higher dividends can be used as a tool to mitigate the agency problems of firms. On the free cash flow hypothesis, Jensen \& Michael, (1986) argues that dividends are paid after investment decisions. While the tax preference theory of Miller and Scholes, (1978) states that tax factor divide investors into different clientele, the catering theory of dividend by Baker \& Wurgler (2004) posits that managers tend to give incentives to the investors according to their expectations to cater for them. Till date, dividend policy is still listed as one of the top ten crucial unresolved issues in the world of finance in which no consensus has been reached (Brealey \& Myers, 2005).

Consequently, examining the determinants of dividend policy has attracted significant research interest over a period of time. There are several researchers that have carried out this study (Duha, 2009; Nguyen, 2012; Rehman \& Takumi, 2012; Arif \& Akbar, 2013, Maniagi, Ondiek, Musiega, Maokomba\&Egessa, 2013; Uwuigbe, 2013; Maladjian \& El Khoury, 2014; Ahmed \& Imran, 2014; Oyinlola, Oyinlola \& Adeniran, 2014; Bahaa, 2015; King'wara, 2015; and Bogna, 2015). Most of these studies concentrated on other sectors of the economy with the petroleum sector receiving limited research attention. 
Also, the extent to which profitability, firm size, liquidity and leverage affects the dividend policy of petroleum firms in Nigeria have been left unanswered. Therefore, this study attempts to fill the gap in existing literature by evaluating the determinants of dividend policy of petroleum firms in Nigeria.

\subsection{Objectives of the Study}

The main objective of the study is to evaluate the determinants of dividend policy of petroleum firms in Nigeria. The specific objectives are;

i. Examine the impact of profitability on dividend policy of petroleum firms in Nigeria.

ii. Examine the impact of firm size on dividend policy of petroleum firms in Nigeria.

iii. Examine the impact of Liquidity on the divided policy of Petroleum firms in Nigeria.

iv. Examine the impact of Leverage on the divided policy of Petroleum firms in Nigeria.

\section{Literature Review}

Dividend decision is one of the core decision areas of financial management (Onoja, 2015). Uwuigbe, Jafaru \& Ajayi, (2012) described dividend as an appropriation of profits to shareholders after deducting tax and fixed interest obligations on debt capital. Dividend represents a distribution of earnings to the shareholders of a company that are usually declared at the Annual General Meetings and paid to shareholders. According to Olimalade \& Adewumi, (1987), it is seen as cash flows that accrue to equity investors. Dividend is a form of return to shareholders on their investment with the aim of increasing their confidence in the future of the company in which they have invested.

The determinants of dividend policy have been examined by several authors over the years. Dada and Malomo (2015) critically evaluated the determinants of dividend policy of Nigerian banks. The study was based on panel data of selected Banks that are listed on the Nigerian Stock Exchange (NSE) having financial data for 2008 to 2013 that was covered in the study. The appropriate diagnostic test on the data was conducted using the data Skewness and Kurtosis test of the data distribution normality while the relationship between the variables was tested using the panel least square regression analysis, however robustness of the result was confirmed with the correlation analysis. The study revealed that Dividend payment is positively related with leverage, performance, corporate governance and last year dividend while it is negatively related with firm's liquidity. The study confirms the relevance of the Agency theory to the Banks Dividend Policy while the future dividend can be predicted based on the current dividend.

King'wara, (2015) carried out a study on determinants of dividend payout ratios in Kenya. He examined the effect of six factors including earnings of the firm, ratio of retained earnings to total assets, firm size, growth opportunities, leverage and market value, shown to influence dividend policies in companies operating in developed countries on companies operating in Kenya, a developing economy using a Tobin Regression model. It was observed that dividend payout ratio is impacted negatively by the growth rate, debt ratios and firm size and positively by earnings, market-to-book ratio and retained earnings to total assets ratio.

Bahaa, (2015) also researched on determinants of dividend policy in Kuwait Stock Exchange (KSE).The study used a firm-level panel data set of publicly traded firms on the Stock Exchange between 2011 and 2014. Three determinants were employed (company size, profitability and financial leverage) and the data analyzed within the framework of OLS regression technique. The results revealed that the dividend policy in KSE Market is positively affected by leverage and risk and were negatively affected by profitability, and company size. Consequently, it was discovered that the major determinants of dividend policy of the firms in KSE are profitability, leverage, level of risk and size.

Ahmed, Imran \& Ali, (2014) researched on the determinants of corporate dividend policy in Pakistan banking sector. Panel data of four banks were collected from 2008 to 2011 from audited financial statements. The results showed that income is negatively related with dividend payout and cannot be considered the only determinant of dividend payments in banking sectors of Pakistan. Other factors like Reserves, EPS, and Interest Income also showed a significant impact on dividend payment pattern of commercial banks in Pakistan.

Yegon, Chenugot, and Sang (2014) examined the relationship between dividend policy and firm's profitability, investment and Earning per Shares. Data for the study were extracted from annual report and accounts of Nine (9) quoted manufacturing companies in Kenya. The datawere subjected to regression analysis, using e-view software and the findings indicate that; there is a significant positive relationship between dividend policies of organizations and firm's profitability, there is also a significant positive relationship between dividend policy and investments and there is a significant positive relationship between dividend policy and Earnings Per Share.

Maladjian and El Khoury, (2014) carried an investigation on the factors determining the dividend payout policy in the Lebanese banks listed on the Beirut Stock Exchange. The study considered the impact of seven variables, namely; profitability, liquidity, leverage, firm size, growth, firm risk and previous year's dividend payout on the dividend payout ratios by using an unbalanced panel data set of listed banks between the 
years of 2005 and 2011. Two models were tested using the OLS and the dynamic panel regressions. Empirical results showed that the dividend payout policies are positively affected by the firm size, risk and previous year's dividends, but are negatively affected by the opportunity growth and profitability.

Maniagi, Ondiek, Musiega, Maokomba, and Egessa, (2013) examined the determinants among dividend payout of non-financial firms listed on Nairobi Securities Exchange. A Purposive sampling technique was used and a sample of 30 non-financial companies for duration of five years from 2007 to 2011 was selected. Secondary data was collected from audited financial statements of companies from Nairobi Securities Exchange website and the websites of non-financial firms'. Dividend payout ratio was dependent variable while independent variables were profitability, Growth, current earnings, and liquidity. Size and business risk was taken as moderating variables. Descriptive statistics and multiple regressions were used. Return on equity current earnings and firms' growth activities were found to be positively correlated to dividend payout Business risk and size, both the two taken as moderating variables increase the precision of significant variables from $95 \%$ to $99 \%$ hence among major determinants of dividend payout.

Oyinlola, Oyinlola and Adeniran (2014) examined the performance impact of dividend policy in the brewery industry. Only secondary data were used and were collected on the internet. They were analysed using descriptive statistics, correlation analysis and regression analysis. Findings, however, revealed that dividend policy is relevant and that a firm's dividend policy is seen as a major determinant for a firms' performance.

Uwuigbe (2013) investigated the determinants of dividends policy in the Nigerian stock exchange market. To achieve the objectives of the study, a total of 50 listed firms in the Nigerian stock exchange market were selected and analyzed for the study using the judgmental sampling technique. Also, the corporate annual reports for the period 2006-2011 were used for the study. The paper was basically modelled to examine the effects of financial performance of firms, firm size, financial leverage and board independence on the dividend payout decisions of listed firms operating in the Nigerian stock exchange market using the regression analysis method. The study in its findings observed that there is a significant positive relationship between firms' financial performance, size of firms and board independence on the dividend payouts decisions of listed firms in Nigeria.

Nnadi, Wogboroma and Kabel (2013) examined the determinants of dividend policy in African Stock Exchanges. Using available financial data of listed firms in the 29 stock exchanges in Africa, the study found similarities in the determinants of dividend policy in African firms with those in most developed economies. In particular, agency costs were found to be the most dominant determinant of dividend policy among African firms. The finding is non-synonymous with emerging capital markets which have a high concentration of private ownership and trading volumes. The study also found that other factors such as level of market capitalisation, age and growth of firms, as well as profitability also play key roles in the dividend policy of listed African firms.

Trang, (2012) carried out a study on the determinants of dividend policy in Vietnam, an emerging stock market that was officially established in July, 2000. The study identified whether firms' characteristics and corporate governance affect their dividend payments. Firms' characteristics included profitability, firm size, debt level, liquidity, asset structure, industry type, growth opportunities plus business risk; corporate governance comprised of management ownership, ownership concentration, and board of directors along with audit quality. The study was based on a sample of 116 companies listed on the Hochiminh Stock Exchange (HOSE) and Hanoi Stock Exchange (HNX) for the year of 2009 in Vietnam. Being similar to studies in the US, the UK, Argentina, Tunisia and Poland, it was found that, in Vietnam, profitability influences positively and business risk impacts negatively on dividend disbursement. Moreover, there are relationships between industry type as well as audit quality and dividend payments.

Abdul \& Aruto, (2012) examined the determinants of dividend payout ratio in the largest stock exchange of Pakistan i.e. Karachi Stock Exchange (KSE). The effect of Debt to equity ratio, Operating cash flow per share, profitability, market to book value ratio, current ratio and corporate tax on dividend payout ratio was analyzed for the year 2009 for 50 companies that announced dividend in 2009. Relation of debt to equity ratio, profitability, current ratio and corporate tax was found to be positive with dividend payout ratio while Operating cash flow per share and market to book value ratio has a negative relationship with dividend payout ratio. Profitability, debt to equity and market to book value ratios were found to be the significant determinants of dividend payout ratio in Pakistan.

Arif \& Akbar, (2012) evaluated the determinants of dividend policy. The study was conducted on nonfinancial sector of Pakistan. Five important determinants were identified in the study; profitability, size, tax, investment opportunities and life cycle stage of firm. A sample of 174 non-financial firms listed on Karachi Stock Exchange for the period of 2005 to 2010 was chosen for the study. The results identified profitability, tax, size and investment opportunities as the most influential determinants of dividend policy.

Al-Kuwari (2009) investigates the determinants of dividend policies for firms listed onGulf Cooperation Council (GCC) country stock exchanges. This study used a panel dataset of non-financial firms listed 
on the GCC country stock exchanges between the years of 1999 and 2003. Seven hypotheses pertaining to agency cost theory were investigated using a series of random effect Tobit models. The models considered the impact of government ownership, free cash flow, firm size, growth rate, growth opportunity, business risk, and firm profitability on dividend payout ratios. The results suggested that the main characteristics of firm dividend payout policy were that dividend payments related strongly and directly to government ownership, firm size and firm profitability, but negatively to the leverage ratio. These results, taken as a whole, indicate that firms pay dividends with the intention of reducing the agency problem and maintaining firm reputation, since the legal protection for outside shareholders was limited.

The determinants of dividend policy have received significant research attention overtime. These researchers however examined the determinants of dividend on several sectors of the economy with the petroleum sector receiving limited research attention. This study therefore fills the gap in literature by evaluating the determinants of dividend policy of petroleum firms in Nigeria.

\section{Methodology}

This study adopts an ex-post facto research design due to its strength in ascertaining the impact of past factor(s) on the present happening or event and being one of the most appropriate designs for studies that use secondary data. To achieve the objectives of the study, the annual reports of nine (9) petroleum marketing firms listed on the Nigerian stock Exchange for the period 2011-2014 were examined. The firms included; Oando Plc, Conoil Plc, Eterna Plc, Forte Oil Plc, JAPAUL Oil and Maritine Services, Beco Plc, Mobil Oil Plc, Total Nigeria Plc and MRS Oil Nigeria Plc. The sample period from 2011 to 2014 was selected in relation to data availability suitable for the study. Nevertheless, in order to re-examine the research hypotheses stated below, the ordinary least square (OLS) data estimation method was used. Data shall be analyzed using E view (version 7.0) statistical package for the study.

\subsection{Research Hypotheses}

$\mathbf{H}_{\mathbf{0 1}}$ :Profitability has no significant impact on the dividend policy of petroleum firms in Nigeria.

$\mathbf{H}_{\mathbf{0} 2}$ :Firm Size has no significant impact on the dividend policy of petroleum firms in Nigeria.

$\mathbf{H}_{\mathbf{0}}$ : Liquidity has no significant impact on the dividend policy of petroleum firms in Nigeria

$\mathbf{H}_{\mathbf{0} 4}$ :Leverage has no significant impact on the dividend policy of petroleum firms in Nigeria

\subsection{Model Specification}

The following linear regression model has been formulated to guide the researcher in the investigation.

Dividend Policy $=f$ (Determinants)

$D P R=f(R O A, T A, L R, L E V, R O E)$

$D P R=\alpha+\beta_{1} \mathrm{ROA}+\beta_{2} \mathrm{TA}+\beta_{3} \mathrm{LR}+\beta_{4} \mathrm{LEV}+\beta_{5} \mathrm{ROE}+\mu$

Where;

$\mathrm{DPR}=$ Dividend Payout Ratio. This is the proxy for dividend policy. It is the percentage of the company's earning distributed to shareholders. It is determined as the ratio of dividend paid to net income. The approach was followed by Bonga (2015), Dada, Malomo and Ojediran (2015), Maladjian and El Khoury (2014) and AlKuwari (2009).

$\mathrm{ROA}=$ Return on Assets: This is the proxy for profitability. The ROA is an indicator of how profitable a company is relative to its total assets. ROA is determined as a ratio of net profit after tax to total assets. The approach was followed by Bonga (2015), Dada, Malomo and Ojediran (2015), Maladjian and El Khoury (2014), Nuhu, et al (2014), Arif \& Akbar, (2012) and Al-Kuwari (2009).

$\mathrm{TA}=$ Total Asset. The firm size in the study is measured by the natural logarithm of Total Assets (TA) as used by Bonga (2015), Dada, Malomo and Ojediran (2015), El Khoury and Maladjian (2014), Maladjian and El Khoury (2014), Nuhu, Musah and Senyo (2014) and Maniagi, et al, (2013).

$\mathrm{LR}=$ Liquidity Current Ratio. This is a proportion between current assets and current liabilities, is used as a proxy for liquidity. It is determined as a ratio of current assets to current liabilities. This approach is followed by Bonga (2015), Dada, Malomo and Ojediran (2015), El Khoury and Maladjian (2014), Maladjian and El Khoury (2014), Nuhu, Musah and Senyo (2014) and Maniagi, et al, (2013).

$\mathrm{LEV}=$ Leverage. Leverage is the ratio of a company loan capital to the value of its asset holding. It is determined as a ratio of Total Debt to Total Asset. This approach is followed by Awad (2015).

$\mathrm{ROE}=$ Return on Equity. This is the returns accruable to shareholders from their equity holdings. It is determined as a ratio of Net Profit after Tax to Total Equity or Shareholders' Fund. This approach is followed by Maniagi et al. (2013). 


\section{Results and Discussion}

Table 1 as presented in the appendices section presents a univariate summary of the variables employed in the study. The value of $\mathrm{N}$ stood at 36, indicating that the Number of Observation comprises of 9 petroleum firms for a period of 4 years. Dividend Payout Ratio (DPR) reveals a minimum, maximum, mean and standard deviation of $-0.1370,3.9850,0.622476$ and 0.9624286 respectively. This indicates that some of the firms' dividend policy allows payment of dividend even when loss is incurred hence a DPR of -0.1370 . The maximum DPR during the period under investigation stood at 3.9850. On average, the percentage of the firms earning distributed to shareholders during the study period stood at $62.25 \%$ with fluctuations to the tune of 0.9624286 .

Return on Asset (ROA) presents a minimum, maximum, mean and standard deviation of -0.7069 , $0.2177,-0.012226$ and 0.1666310 . This indicates that during the period under investigation, the minimum and maximum value of ROA stood at -0.7069 and 0.2177 respectively. It also reveals that on average, the ratio of profit to total assets of the selected firms during the period under investigation was very low at $-1.22 \%$ with fluctuations to the tune of 0.1666310 .

Total Assets (TA) as presented in Table 1 reveals a minimum, maximum, mean and standard deviation of $14141978,385867805,349513664.83$ and 817624025.46 respectively. This implies that during the period under investigation, the minimum and maximum value of total assets stood at $\$ 14,141,978$ and $\$ 385,867,805$. It also implies that with fluctuations to the tune of 817624025.46 , the average value of total assets of the firms during the period under investigation stood at $\$ 349,513,664.83$.

Liquidity Ratio (LR) reveals a minimum, maximum, mean and standard deviation of 0.0340, 6.3951, 1.229703 and 1.1928020 respectively. This indicates that during the study period, the minimum liquidity ratio reported by firms stood at 0.0340 while the maximum stood at 6.3951 . It also indicates that on average, the ratio of current assets to current liabilities during the period under investigation stood at 1.229703 with fluctuations to the tune of 1.1928020 .

Leverage Ratio (LEV) presents a minimum, maximum, mean and standard deviation of $0.0000,1.8631$, 0.704508 and 0.3789347 respectively. This indicates that the minimum leverage position of firms under investigation stood at 0.0000 while the maximum stood at 1.8631 . It also indicates that the average debt in the capital structure of the sampled firms during the study period was high $(70.45 \%)$ with fluctuations amounting to 0.3789347 . Return on Equity (ROE) presents a minimum, maximum, mean and standard deviation of -3.6181 , $0.9076,-0.064609$ and 0.8537968 respectively. This implies that during the study period, the minimum returns accrued to shareholders from their equity holding stood at -3.6181 while the maximum stood at 0.9076 . Also, on average, ROE stood at -0.064609 with fluctuations to the tune of 0.8537968 .

Table 2 as contained in the appendices of the study presents the correlations analysis of the study variables. It describes the relationship existing between the dependent variable; DPR and the independent variables; ROA, TA, LR and LEV. ROA presents a correlation coefficient of -0.335 with a significance value of 0.046. This implies that there is a negative, weak and but significant relationship existing between DPR and ROA of listed petroleum firms in Nigeria. Total Asset (TA) presents a correlation coefficient and significance value of 0.146 and 0.395 respectively. This indicates that there is weak, positive and insignificant relationship between dividend payout ratio and total assets of the firms under investigation. The positive relationship here implies that as total assets increases, dividend payout ratio also increases. Liquidity Ratio (LR) presents a correlation coefficient of -0.210 and a significance value of 0.220 , indicating that there is a weak negative and insignificant relationship between dividend payout ratio and liquidity ratio of the firms. Leverage Ratio (LEV) presents a correlation coefficient of 0.027 and a significance value of 0.875 , indicating a weak, positive, and insignificant relationship between dividend payout ratio and leverage ratio of the listed petroleum firms under investigation. Return on Equity (ROE) presents a correlation coefficient and significance value of -0.014 and 0.938 respectively. This indicates a weak, negative and insignificant relationship existing between dividend payout policy and return on equity of listed petroleum firms in Nigeria.

Table 3 as presented in the appendices displays the results of the explanatory variables; Return on Assets (ROA), Total Assets (TA), Liquidity Ratio (LR), Leverage Ratio (LEV), and Return on Equity (ROE) regressed with a common dependent variable; Dividend Payout Ratio (DPR). As revealed in the Table reflects the R-squared $\left(R^{2}\right)$ value of $0.317 . R^{2}$ which is the coefficient of determination, measures the percentage of the total change in the dependent variable; Dividend Payout Ratio (DPR) that can be explained by the independent or explanatory variables; Return on Assets (ROA), Total Assets (TA), Liquidity Ratio (LR), Leverage Ratio (LEV), and Return on Equity (ROE). Thus the $\mathrm{R}^{2}$ value of 0.317 indicates that Return on Assets (ROA), Total Assets (TA), Liquidity Ratio (LR), Leverage Ratio (LEV), and Return on Equity (ROE) account for $31.7 \%$ of the total variation in the Dividend Payout Ratio (DPR) of listed petroleum firms in Nigeria while the remaining $68.3 \%$ (100-31.7) of the variation could be explained by other variables not considered in this model. The adjusted $\mathrm{R}$ as shown in Table 3 reflects a value of 0.203 , indicating that if the entire population is considered in this model, the result will deviate by $11.4 \%$ (31.7-20.3). The significant $\mathrm{F}$ change as revealed in Table 3 reflects a value of 0.035 which is less than 0.05 , indicating that the whole model is statistically significant at $5 \%$ level of 
significance. The regression results as presented in Table 3 above to determine the influence of Return on Assets (ROA), Total Assets (TA), Liquidity Ratio (LR), Leverage Ratio (LEV), and Return on Equity (ROE) on the Dividend Payout Ratio (DPR) revealed that when all the predictor variables are held stationary, DPR is estimated at 0.415 . Table 3 further predicts the dependent variable DPR, using the independent variables ROA, TA, LR, LEV and ROE such that a unit change in (ROA), Total Assets (TA), Liquidity Ratio (LR), Leverage Ratio (LEV), and Return on Equity (ROE) will bring about a change in the Dividend Payout Ratio (DPR) by $5.172,-1.293,-013, \quad-0.087,0.436$ and 0.861 respectively.

\subsection{Test of Hypotheses}

The four hypotheses formulated in this study are tested using the P-value statistics. The null hypothesis for variables with p-values less than 0.05 is rejected and vice versa.

\section{Hypothesis One}

$\mathbf{H}_{\mathbf{0} 1}$ : $\quad$ Profitability has no significant impact on the dividend policy of petroleum firms in Nigeria

Given that the calculated p-value as presented in Table 4 is 0.0029 and less than 0.05 , the null hypothesis is rejected and the study concludes that profitability has a significant impact on the dividend policy of petroleum firms in Nigeria.

\section{Hypothesis Two}

$\mathbf{H}_{\mathbf{0} 2}$ : $\quad$ Firm Size has no significant impact on the dividend policy of petroleum firms in Nigeria

Given that the calculated p-value as presented in Table 4 is 0.9996 and greater than 0.05 , the null hypothesis is accepted and the study concludes that firm size has no significant impact on the dividend policy of petroleum firms in Nigeria.

\section{Hypothesis Three}

$\mathbf{H}_{\mathbf{0 3}}$ : $\quad$ Liquidity has no significant impact on the dividend policy of petroleum firms in Nigeria

Given that the calculated p-value as presented in Table 4 is 0.4906 and greater than 0.05 , the null hypothesis is acceptedand the study concludes that liquidity has no significant impact on the dividend policy of petroleum firms in Nigeria.

\section{Hypothesis Four}

$\mathbf{H}_{\mathbf{0 4}}$ : $\quad$ Leverage has no significant impact on the dividend policy of petroleum firms in Nigeria

Given that the calculated p-value as presented in Table 4 is 0.3705 and greater than 0.05 , the null hypothesis is accepted and the study concludes that liquidity has no significant impact on the dividend policy of petroleum firms in Nigeria.

\section{Conclusion and Recommendations}

This study evaluated the determinants of dividend policy of petroleum firms in Nigeria. In line with the findings of the study, it is concluded that profitability is one of the most considered determinants of dividend policy by listed petroleum firms in Nigeria. The firms however are less affected by firm size and liquidity position in making dividend policy decisions.

In line with the findings of the study, it is recommended investors in petroleum industry who prefer to have dividends yearly should invest in more profitable firms as they tend to pay more dividends. Also, they should not be convinced by the firms' size and liquidity position as they do not greatly influence the dividend payout decision of listed petroleum firms in Nigeria. Furthermore, managers of petroleum firms should aim at having high dividend payout which will improve investors' confidence in the firm hence leading to increase in the firms' value.

\section{References}

[1]. Abor, J., and Bokpin, G. A. (2010). Investment Opportunities, Corporate Finance, and Dividend payout policy: Evidence from emerging markets. Studies in Economics and Finance, 37(3), 180 - 194.

[2]. Afza, T., and Mirza, H. H. (2011). Do mature companies pay more dividends? Evidence from Pakistani Stock Market. Mediterranean Journal of Social Sciences, 2(2), 152 - 161.

[3]. Agrawal, A., and Jayaraman, N. (1994). The Dividend Policies of All Equity Firms: A Direct Test of The Cash Flow Theory. Managerial and Decision Economics, 15 (2), 139-148.

[4]. Ahmed, H., and Javad, A. Y. (2009). Determinants of Dividend Policy in Pakistan. International Research Journal of Finance and Economics , 1-16.

[5]. Ahmed, M. M., Imran, H., and Ali, I. (2014). Determimants of Dividend Policy: An Empirical Study of Banking Sector of Pakistan. Interdisciplinary Journal of Contemporary Research in Business, 5 (11), 360-369.

[6]. Aivazian, V., and Booth, L. (2003). Do emerging firms follow different dividend policies from U.S. firms? Journal of financial Research, 26 (3), 371-387. 
[7]. Allen, F., and Michaely, R. (1995). Dividend Policy: Hand Book in Operations Research on Management Science. Amsterdam: Elservier.

[8]. Al-Malkawi, H. A. N., Rafferty, M., and Pillai, R. (2010). Dividend Policy: A Review of Theories and Empirical Evidence. International Bulletin of Business Administration, (9), $171-200$.

[9]. Al-Twaijry, A. (2007). Dividend Policy and Payout Ratio: Evidence from Kuala Lumpur Stock Exchange. The Journal of Risk Finance, 8 (4), 349-363.

[10]. Arif, A., and Akbar, F. (2013). Determinants of Dividend Policy: A Sectoral Analysis from Pakistan. International Journal of Business and Behavioral Sciences, 3 (9), 16-33

[11]. Bahaa, A. (2015). Determinants of Dividend Policy in Kuwait Stock Exchange. International Journal of Business and Management Review, 7 (3), 72-78.

[12]. Bhattacharya, S. (1979). Imperfect Information, Dividend Policy, and The Bird in the Hand Fallacy. The Bell Journal of Economics, 259-270.

[13]. Bonga, K. (2015). Determinants of Dividend Policy: Evidence from Polish Listed Company. Procedia Economics and Finance, 23, 437-477.

[14]. Brealey, R., and Myers, S. (2005). Principles of Corporate Finance. London: McGraw-Hill, pp. $155-167$.

[15]. Brigham, E., and Gapenski, L. (1998). Financial Management Theory and Practice. New Dheli: Atlantic Publishers and Distributers.

[16]. Chia-ying, C. (2012). The Effects of Executive Stock Options and Stock Bonuses on Payout Policies in Taiwan. Asia-Pacific Journal of financial Studies, 41, 146-174.

[17]. Dada, F.B. (2015). Critical Evaluation of Dividend Policy of Banking Sector in Nigeria. International Journal of Economics, Commerce and Management, 3(2), 1-11.

[18]. Drooms, W., and Wright, J. (2010). Finance and Accounting for Non-Financial Manager: All the basic you need to Know. New York: Basic Books.

[19]. Duha, A. (2009). Determinants of Dividend Policy in Emerging Stock Exchange: The Case of GCC Countries. Global Economy and Finance Journal, 2 (2), 38-63.

[20]. Farinha, J. (2003). Dividend Policy, Corporate Governance and the Managerial Entrenchment Hypothesis: An Empirical Analysis. Journal of Business Finance and Accounting, 30 (9) 1173-1209.

[21]. Gordon, M. J. (1963). Optimal Investment and Financing Policy. The Journal of Finance, 264-272.

[22]. Graham, B., and Dodd, D. (1951). Security Analysis: Principles and Techniques (3rd ed.). New York: McGraw-Hill.

[23]. Guay, W., and Herford, J. (2000). The Cash Flow Performance and Information Content of Dividend Increases Versus Repurchases. Journal of Finance Economics, 57 (3), 385-398.

[24]. Hafeez, A., and Attiya, Y. (2008). Dynamics and Determinants of Dividend Policy in Pakistan: Evidence from Karachi Stock Exchange for Non-Listed Firms. MPRA, 373-421.

[25]. Ho, H. (2003). Dividend Policies in Austraila and Japan. International Advances in Economic Research, 9 (2), $91-100$.

[26]. Jagannathan, M., Stephens, C., and Wasbach, M. (2000). Financial Flexibility and the Characteristics of Dividends and Stock Purchases. Journal of Financial Economics, 57 (3), 355-384.

[27]. Jensen, M. (1986). Agency Cost of Free Cash Flows, Corporate Finance and Takeovers. American Economic Review, 70 (1), 323329.

[28]. Jo, H., and Pan, C. (2009). Why are firms with entrenched managers more likely to pay dividends? Review of Accounting and Finance, 8 (1), 87-116.

[29]. John, K., and Williams, J. (1985). Dividend Dilution and Taxes: A Signalling Equilibrum. Journal of Finance, 40 (4), $1053-1070$.

[30]. King'wara, R. (2015). Detereminants of Dividend Payout Ratios in Kenya. Research Journal of Finance and Accounting, 6 (1), 6.

[31]. Lipson, M., Maquieria, C., and Megginson, W. (1998). Dividend Initiations and Earnings Surprises. Journal of Financial Management, 24, 36-45.

[32]. Mahira, K. (2012). FActors Affecting Dividend Payout: Evidence from Listed Non-Financial firms of Karachi Stock Exchange. Business Management Dynamics, 1 (11), 76-92.

[33]. Maniagi, G., Ondiek, B., Musiega, D., Maokomba, O., and Egessa, R. (2013). Determinants of Dividend Payout among NonFinancial Firms on Nairobi Securities Exchange, Kenya. International Journal of Science and Technology Research, 2 (10), $253-$ 266.

[34]. Manigagi, G. M., and El Khoury, R. (2014). Determinants of Dividend Policy. International Journal of Economics and Finance, 6 (4), 240-256.

[35]. Mehar, A. (2002). Corporate Governance and Dividend Policy. MPRA, 619 (1), 13-29.

[36]. Miller, M. H., \& Modigliani, F. (1961). Dividend Policy, Growth, and the Valuation of Shares. The Journal of Business, $411-433$.

[37]. Miller, M., and Scholes, M. (1978). Dividend and Taxes. Journal of Financial Economics, 6 (4), $333-364$.

[38]. Myers, M., and Bacon, F. (2004). The Determinants of Corporate Dividend Policy. Academy of Accounting and Financial Studies Journal, 8 (3), 17-28.

[39]. Nguyen, T. (2012). Detreminants of Dividend Policy: The Case of Vietnam. International Journal of Business Economics and Law, $1,48-57$.

[40]. Nissm, D., and Ziv, D. (2001). Dividend Changes and Future Profitability. Journal of Finance, 56 (6), $2111-2133$.

[41]. Nnadi, M., Wogboroma, N., and Bariyima, K. (2012). Determinants of Dividend Policy: Evidence from Listed Firms in African Stock Exchanges. Paneconomics, 6,725-741.

[42]. Olimalade, A., and Adewumi, W. (1987). Business Finance: Issues and Topics. Ibadan: University Press.

[43]. Oyinlola, O.M., Oyinlola, F.O., and Adeniran, J.O. (2014). The influence of Dividend Payout in the Peroformance of Nigerian Listed Brewery Companies. International Journal of Economics and Management Science, 3(1), 13-21.

[44]. Pandey, M.(2004) Financial Management .Vikas Publishing House PVT Limited

[45]. Rehman, A., and Takumi, A. (2012). Detereminants of Dividend Payout Ratio: Evidence from Karach Stock Exchange. Journal of Contemporary Issues in Business Research, 1 (1), 20-27.

[46]. Rozeff, M. (1982). Growth beta and Agency Costs as Dterminants of Dividend Payout Ratios. Journal of Financial Research, 5 (3), 249-259.

[47]. Taher, A. (2012). Determinants of Dividend Payout Policy: Evidence from Bangladash. International Journal of Economic Practices, 2 (3), 11-27.

[48]. Uwuigbe, O.R. (2013). Dterminants of Dividend Policy: A Study of Selected Listed Firms in Nigeria. Manager, 17,107-119.

[49]. Uwuigbe, U., Jafaru, J., and Ajayi, A. (2012). Dividend Policy and Firm Performance: A Study of Listed firms in Nigeria. Accounting and Management Information Systems, 11 (3), 442-454. 
[50]. Yegon, C., Cheruiyot, J., and Sang, J. (2014). Effects of Dividend Policy of Firms' Financial Performance: Econometric Analysis of Listed Manufacturing Firms in Kenya. Research Journal of Finance and Accounting, 5(12), 136-144.

Appendices

Table 1 Descriptive Statistics

\begin{tabular}{|l|c|c|c|c|c|c|}
\hline \multicolumn{1}{|c|}{ Statistics } & DPR & ROA & TA & LR & LEV & ROE \\
\hline Minimum & -0.137 & -0.7069 & 14141970 & 0.034000 & 0.000000 & -3.6181 \\
\hline Maximum & 3.985000 & 0.217700 & $3.86 \mathrm{E}+09$ & 6.395100 & 1.863100 & 0.907600 \\
\hline Mean & 0.622472 & -0.01222 & $3.50 \mathrm{E}+08$ & 1.229706 & 0.704500 & -0.06461 \\
\hline Std. Dev. & 0.962430 & 0.166635 & $8.18 \mathrm{E}+08$ & 1.192803 & 0.378932 & 0.853803 \\
\hline Observations & 36 & 36 & 36 & 36 & 36 & 36 \\
\hline
\end{tabular}

Table 2 Correlations

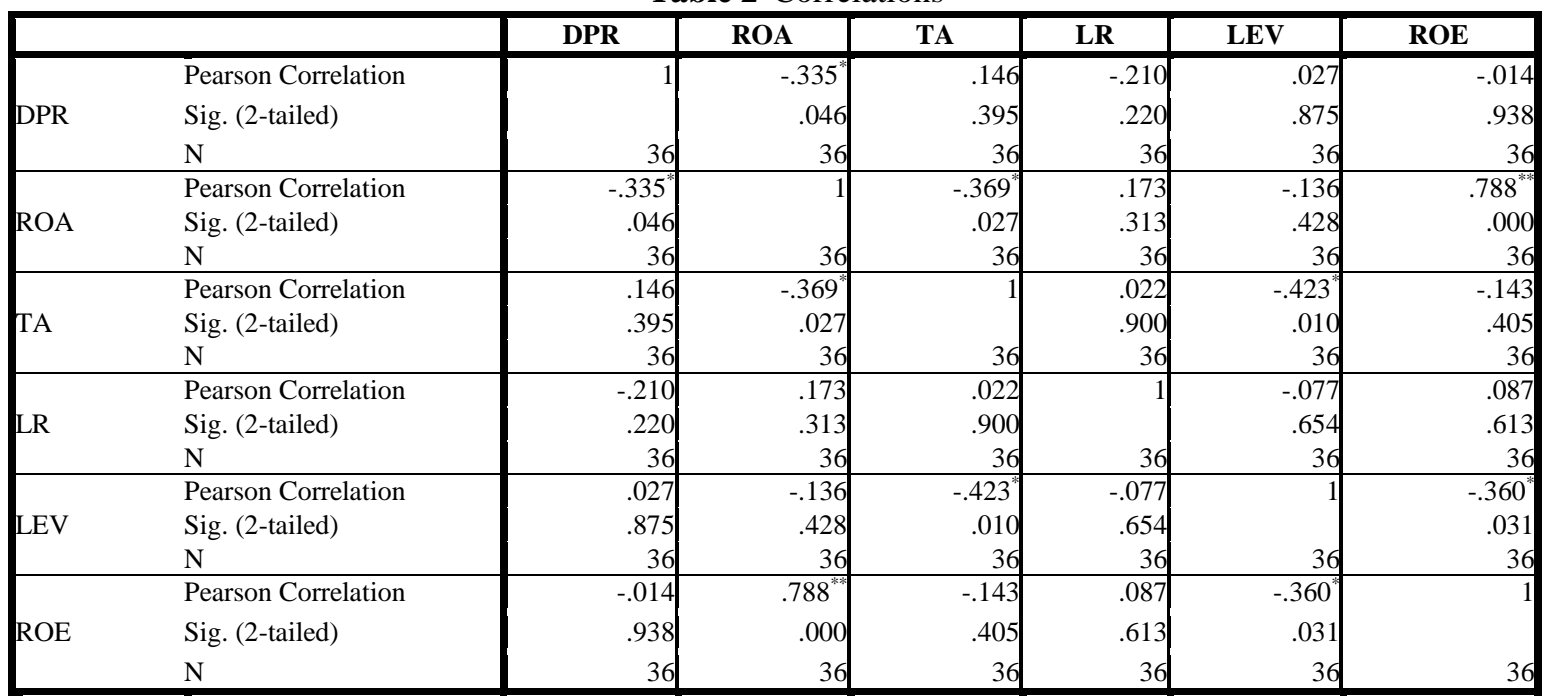

*. Correlation is significant at the 0.05 level (2-tailed).

**. Correlation is significant at the 0.01 level (2-tailed).

Table 3 Regression Analysis

Dependent Variable: DPR

Method: Least Squares

Date: 03/22/17 Time: 03:41

Sample: 136

Included observations: 36

\begin{tabular}{ccccc} 
Variable & Coefficient & Std. Error & t-Statistic & Prob. \\
\hline \hline C & & & & \\
ROA & 0.414869 & 0.433318 & 0.957426 & 0.346 \\
TA & -5.17298 & 1.598142 & -3.23687 & 0.9996 \\
LR & $-1.15 \mathrm{E}-13$ & $2.24 \mathrm{E}-10$ & -0.00051 & 0.4906 \\
LEV & -0.08725 & 0.125012 & 0.3705 \\
ROE & 0.436265 & 0.479885 & 0.909103 & 0.0086 \\
\hline \hline R-squared & 0.861127 & 0.306482 & 2.80972 & 0.622472 \\
Adjusted R-squared & 0.317367 & Mean dependent var & & 0.96243 \\
S.E. of regression & 0.203594 & S.D. dependent var & & 2.684655 \\
Sum squared resid & 0.858888 & Akaike info criterion & & 2.948575 \\
Log likelihood & 22.13065 & Schwarz criterion & & 2.77677 \\
F-statistic & -42.3238 & Hannan-Quinn criter. & & 2.028011 \\
Prob(F-statistic) & 2.78949 & Durbin-Watson stat & & \\
\hline \hline
\end{tabular}


Determinants of Dividend Policy of petroleum firms in Nigeria

Data Relating to the Study Variables

\begin{tabular}{|c|c|c|c|c|c|c|c|}
\hline FIRMS & YEAR & DPR & ROA & TA & LR & LEV & ROE \\
\hline \multirow[t]{4}{*}{ Conoil } & 2011 & 0.4630 & 0.0485 & 61855315 & 1.2533 & 0.7303 & 0.1797 \\
\hline & 2012 & 2.4265 & 0.0086 & 83095975 & 1.1663 & 0.8115 & 0.0457 \\
\hline & 2013 & 0.2260 & 0.0373 & 82372026 & 1.2087 & 0.781 & 0.1702 \\
\hline & 2014 & 3.3266 & 0.0096 & 86593457 & 1.163 & 0.8141 & 0.0518 \\
\hline \multirow[t]{4}{*}{ Forte } & 2011 & 0.0000 & -0.3693 & 42299943 & 0.7741 & 0.8714 & -2.8722 \\
\hline & 2012 & 0.0000 & 0.0175 & 37464000 & 0.6698 & 0.8172 & 0.0956 \\
\hline & 2013 & 0.0000 & 0.0702 & 65316089 & 0.9735 & 0.8111 & 0.3714 \\
\hline & 2014 & 1.6375 & 0.0282 & 93678406 & 0.9154 & 0.8711 & 0.2186 \\
\hline \multirow[t]{4}{*}{ Total } & 2011 & 0.7123 & 0.0649 & 58719810 & 0.8778 & 0.8293 & 0.3803 \\
\hline & 2012 & 0.7269 & 0.0614 & 76067065 & 0.8997 & 0.8514 & 0.4133 \\
\hline & 2013 & 0.0000 & 0.0672 & 79403587 & 0.8886 & 0.8332 & 0.4029 \\
\hline & 2014 & 0.0000 & 0.0463 & 95512428 & 0.8948 & 0.8542 & 0.3176 \\
\hline \multirow[t]{4}{*}{ MRS } & 2011 & 0.4912 & 0.0085 & 72700238 & 1.0479 & 0.7388 & 0.0324 \\
\hline & 2012 & 0.9880 & 0.0037 & 55595688 & 1.1035 & 0.6573 & 0.0108 \\
\hline & 2013 & 0.1501 & 0.0097 & 65694626 & 1.0806 & 0.7012 & 0.0323 \\
\hline & 2014 & 0.1497 & 0.0129 & 57846626 & 1.1617 & 0.6505 & 0.0369 \\
\hline \multirow[t]{4}{*}{ JAPAUL } & 2011 & 0.0000 & 0.0345 & 25283218 & 6.3951 & 0.1196 & 0.0392 \\
\hline & 2012 & -0.1370 & 0.0276 & 33161470 & 3.0852 & 0.4064 & 0.0526 \\
\hline & 2013 & 0.0000 & 0.0022 & 17363760 & 3.5257 & 1.2695 & 0.0022 \\
\hline & 2014 & 0.0000 & -0.1631 & 14486732 & 1.9232 & 1.4200 & -0.124 \\
\hline \multirow[t]{4}{*}{ Mobil } & 2011 & 0.7067 & 0.2177 & 18748647 & 0.2735 & 0.7601 & 0.9076 \\
\hline & 2012 & 0.4179 & 0.1068 & 33663722 & 0.9476 & 0.4349 & 0.5455 \\
\hline & 2013 & 0.3795 & 0.1166 & 40728522 & 0.7498 & 0.4127 & 0.4981 \\
\hline & 2014 & 0.0000 & 0.1255 & 49217575 & 0.7503 & 0.7249 & 0.4558 \\
\hline \multirow[t]{4}{*}{ Oando } & 2011 & 0.4464 & 0.0137 & $1.93 \mathrm{E}+08$ & 0.0693 & 0.0133 & 0.0499 \\
\hline & 2012 & 0.4573 & 0.0107 & $5.15 \mathrm{E}+08$ & 0.4755 & 0.8339 & 0.0959 \\
\hline & 2013 & 2.1768 & 0.0089 & $2.63 \mathrm{E}+08$ & 0.8873 & 1.1985 & 0.0222 \\
\hline & 2014 & -0.0881 & -0.3684 & $2.78 \mathrm{E}+08$ & 0.7364 & 1.8631 & -3.6181 \\
\hline \multirow[t]{4}{*}{ BECO } & 2011 & 0.1972 & 0.0676 & $3.86 \mathrm{E}+09$ & 3.4487 & 0.2379 & 0.0887 \\
\hline & 2012 & 3.9850 & -0.7069 & $2.32 \mathrm{E}+09$ & 0.1063 & 0.4376 & -1.257 \\
\hline & 2013 & 0.0000 & -0.0707 & $2.01 \mathrm{E}+09$ & 0.034 & 0.0000 & -0.1226 \\
\hline & 2014 & 0.0000 & -0.2003 & $1.72 \mathrm{E}+09$ & 0.1231 & 0.0005 & -0.4215 \\
\hline \multirow[t]{4}{*}{ Eterna } & 2011 & 0.0000 & 0.0842 & 14141978 & 0.9933 & 0.6315 & 0.2185 \\
\hline & 2012 & 0.6671 & 0.0238 & 32444467 & 1.0215 & 0.8111 & 0.1207 \\
\hline & 2013 & 0.9970 & 0.0347 & 17122764 & 1.2925 & 0.6068 & 0.0835 \\
\hline & 2014 & 0.9054 & 0.0697 & 18048814 & 1.3524 & 0.5561 & 0.1495 \\
\hline
\end{tabular}

Source: Annual Reports of Listed Petroleum Firms in Nigeria from 2011 to 2014 